\title{
Fiscaoeconomia
}

E-ISSN: 2564-7504

2022, Volume 6, Issue 1, 40-58

https://dergipark.org.tr/tr/pub/fsecon

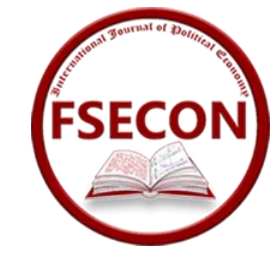

\section{Türkiye Demokrasisinde Çekişmeci Kolektif Eylemlerin Eksikliği}

\section{The Lack of Contentious Collective Actions in Turkish Democracy}

\section{Yavuz YILDIRIM ${ }^{1}$}

\section{Öz}

Kamusal otoritelere yönelik tabandan yükselen düzenli baskılar, şikayetler, gerginlikler ve talepler modern siyasetin şekillenmesinde etkili olmuşlardır. Bu tarz mücadeleler, monarşilerden cumhuriyete ve demokrasilere geçişte tarihsel öneme sahiptir. Günümüzde bu dönüştürücülük devrimci nitelikte olmasa da önemini kaybetmiş sayılmaz. Demokrasilerin göstergeleri bağlamında bu yönde çekişmelerin varlı̆ı her zaman temel kriterler arasındadır. Toplumsal muhalefetin demokrasiyi daha iyi hale getirme yolunda yeni mekanizma ve süreçleri geliştirmesi gerekmektedir. Türkiye'nin sorunlu demokrasi tarihindeki en önemli eksikliklerden birinin, kurumsal siyasetin toplumsal hareketlerin kolektif eylemleri tarafından yönlendirilememesi olduğu söylenebilir. Çoğunlukla odaklanılan karar vericiler ve güç odakları dışında, bir siyasal sistemin analizi muhalefet güçleriyle de alakalıdır. Çalışma "Türkiye'nin güçlü toplumsal muhalefeti ve onun içinde beslenen etkili toplumsal hareketleri var mı?" sorusu etrafinda, toplumsal hareketlerin belirleyici gücünün eksikliği ile Türkiye demokrasisi arasında bağı analiz etmektedir. Mevcut hegemonyanın kurduğu sosyo-ekonomik ağ kadar, demokratik güçlerin kur(a)madığı ağlar da sistemin gelişiminde üzerinde etkili olmuştur. Çalışmada hareketlerle demokratik sistem arasındaki bağlantılar genel hatlarıyla ortaya konduktan sonra, Türkiye özelinde dinamik çekişmeci aktörlerin eksikliği nedeniyle hareketlerin sistemi dönüştürmekte zorlandığı vurgulanmıştır.

Jel Kodları: D79, Y80, Z19.

Anahtar Kelimeler: Çekişmeci Siyaset, Kolektif Eylemler, Toplumsal Hareketler, Taban Demokrasisi.

\footnotetext{
1 Doç. Dr., Niğde Ömer Halisdemir Üniversitesi, ïBF, Siyaset Bilimi ve Uluslararası illişkiler Bölümü, yavuz.yildirim@ohu.edu.tr, ORCID: 0000-0002-1031-1537
}

Citation/Atıf: Yıldırım, Y. (2022). Türkiye Demokrasisinde Çekişmeci Kolektif Eylemlerin Eksikliği. Fiscaoeconomia, 6(1), 40-58. Doi: 10.25295/fsecon.1037892 
Yıldırım, Y. (2022). Türkiye Demokrasisinde Çekişmeci Kolektif Eylemlerin Eksikliği.

Fiscaoeconomia, 6(1), 40-58. Doi: 10.25295/fsecon.1037892

\begin{abstract}
It can be said that one of the most important defects in the problematic history of democracy in Turkey is the inability of institutional politics to be guided by the collective actions of social movements. The study focuses on the question that "does Turkey have substantial civil opposition and effective social movements sustained in it?" The link between the lack of significant power of social movements and Turkish democracy was analyzed around that question. As well as the socio-economic network established by the current hegemony, the comprehensive networks that popular forces could not establish have been effective on the democratic system. After revealing the connections between the movements and the democratic system in general terms in the study, it is explained the difficulties in transforming democracy through movements because of the lack of dynamic contentious actors in Turkey. Regular challenges, claims, grievances and demands from the grassroots against public authorities are effective elements in the gradual transition from monarchies to republics and then democracies. The fact that collective actions, in which individual demands are transformed, are often trapped within the hierarchical patterns of established politics is one of the indicators of the remarkable lack of a dynamic structure in Turkey's representative government. Social opposition needs to develop alternative mechanisms and processes to improve democracy.
\end{abstract}

Jel Codes: D79, Y80, Z19.

Keywords: Contentious Politics, Collective Actions, Social Movements, Grassroot Democracy.

\title{
1. Giriş
}

Tabandan yükselen eylemler ve bunlarda ortaya konan siyasal talepler, siyasetin kurumsal şekillenişinde tarihsel role sahiptir. Siyasal sistemi demokratik yapan en önemli unsurlardan biri, muhalif grupların varlığı ve sesini duyurabilmesidir. Farklı görüşlerin çekişmesi ve çatışması, -liberal demokrasiler için- yarışması, en nihayetinde çeşitli ortaklaşmalar ve uzlaşma noktaları geliştirebilmeleri, modern demokratik işleyişin temellerini oluşturur. Bu ortamın barışçıl biçimde sürdürülebilmesi için, kolektif eylemlerin ve bunların uzun vadeli süreçte dönüştüğü toplumsal hareketlerin siyasal işleyişi demokratikleştirici nitelikler taşıması gerekir. Farklı grupların temsili açısından bu eylemlerin varlığı, parlamentodaki temsil kadar önemlidir.

Çoğunlukla odaklanılan karar vericiler ve güç odakları dışında, bir siyasal sistemin analizi muhalefet güçleriyle de alakalıdır. Çalışma "Türkiye'nin güçlü toplumsal muhalefeti ve onun içinde beslenen etkili toplumsal hareketleri var mı?" sorusu etrafında toplumsal hareketlerin belirleyici gücünün eksikliği ile Türkiye demokrasisi arasında bağı analiz edecektir. Çünkü Türkiye demokrasi tarihinde pek çok gelişim ve atılım süreçleri yaşansa da süreçteki en önemli eksikliklerden birinin, kurumsal siyasetin toplumsal hareketlerin kolektif eylemleri tarafından yönlendirilememesi olduğu söylenebilir. Öte yandan siyasi partiler bu tarz kolektif protestolarla özellikle birlikte anılmak istememektedir. Kurumsal siyaset ile taban demokrasisi arasındaki bu mesafe, ülkenin demokratikleşememesi yönündeki yapısal krizlerinden biridir.

Hareketlerin siyasal süreçlerdeki aktörleri ve konuları belirleme açısından önemi geniş çapta tartışılmaya devam etmektedir (Fominaya, 2020). Ancak bu hattın Türkçe literatürde güçlü olduğu söylenemez. Bu alanda yakın dönemdeki çalışmaların Türkiye'deki demokrasinin otoriterleşme eğilimlerine ve değişen ekonomi politikalarına odaklandığı görülmektedir 
Yıldırım, Y. (2022). Türkiye Demokrasisinde Çekişmeci Kolektif Eylemlerin Eksikliği.

Fiscaoeconomia, 6(1), 40-58. Doi: 10.25295/fsecon.1037892

(Tansel, 2018; Arat ve Pamuk, 2019; Çınar, 2019; Babacan vd. (eds.), 2021). Çalışma bu yöndeki eksikliğe karşı bir katkı sunmak hedefindedir. Türkiye siyasetine eylemler üzerinden bakışlar artsa (Uysal, 2017) ve-yabancı akademik kaynaklarla karşılaştırıldığında çok düşük seviyede olsa da- Türkçe'de özellikle Gezi Parkı eylemleriyle birlikte toplumsal hareketler üzerinden siyasal sistem ve demokrasi analizleri artmıştır (Ögütle ve Göker (der.), 2014; Yörük ve Yüksel, 2015).

Ancak burada, kavramsal ve tarihsel bir arka plana yaslanarak güncel tartışmaların farklı bir temeli ortaya konacaktır. Hareketler literatürü içinde Türkiye'de çok da yaygın olmayan bir eksene dayanılmaktadır. Çekişmenin dinamiği ve çekişmeci siyaset (McAdam Tarrow ve Tilly, 2001; Tilly ve Tarrow, 2007)kavramlarına atıfla ve siyasal fırsat yapısı yaklaşımı üzerinden devam edecek olan çalışma, Türkiye'de siyasal sistem içinde demokratik sav-geliştirme yönündeki eksikliklere odaklanacaktır. Çekişme, çatışma değil, ısrarlı mücadele içerir. Çalışmanın iddiası, taban eylemlerine dayalı demokrasi eksikliğinin, Türkiye'de geliştirilmeye çalışılan demokratikleşme normlarının sağlam temellere dayanmasını engellediğidir. Demokratik aktörlerin geliştirmekte zorlandığı ağlar nedeniyle siyasal sistem, kurumsal siyaset ve en nihayetinde devlet, kişisel müdahalelerle tanımlanmaktadır. Bu tespit, geçmiş dönemdeki toplumsal mücadeleler geleneğinin, sendikal mücadelenin ya da parti girişimlerinin önemsenmediği anlamına gelmez. Ancak kamu siyasasını etkilemede hareketlerin etkisizliği açık bir durumdur. Burada hareketlerin başarı ya da başarısızlığı gibi, onların dinamikliğiyle çelişkili bir nokta değil, demokratik sistemdeki konumları tartışılmaktadır. Bu eksikliğin, siyasal sürecin tabandan itibaren farklı bir biçime dönüşmesini engellediği savunulacaktır.

Çalışmanın önermesi, yapıların hareketlerle bağı azaldıkça demokratik kapasitelerinin azaldığı şeklindedir. Kurumların ve elitlerin kendi dışındaki pratikleri demokratik olarak görmeme eğilimi karşısında, hareketler demokrasinin alanını değiştirme mücadelesi verir. Bu değişimin genişleme yönünde olması, sistemin kurumsal aktörleri ile kurumsal-olmayan aktörleri arasındaki etkileşimde belirlenmektedir. Bu tespite, Ranciere'in (2007; 2014) uyuşmazlık siyasetinin düzen bozucu müdahalelerinin düzeni kontrol edenler üzerinde yarattığı demokrasi nefreti ile yakın dönem siyasal teorinin hareketler ve kurumsal siyaset arasındaki eleştirel arayışı da katkı sunacaktır (Douzinas, 2015; della Porta, 2015; Mouffe, 2019; Hardt ve Negri, 2019; Tarrow, 2021). Hareketlerin pratik siyasetteki etkisinin artırılmasında koordinasyon, strateji, liderlik ve ortak hedefler belirleme gibi noktaların öne çıkarıldığı bu çalışmalarda, sadece belli grupların tanınma ve hak talepleri değil küresel çapta ortak hayatı şekillendirici çabaların nasıl geliştirileceği tartışılmaktadır. Bu çerçevede, yazıda hareketlerin zorlayıcı eylemleriyle ve müdahaleleriyle desteklenmemiş demokrasinin, teknikleşmiş karar-alma mekanizmalarının kısır döngüsünü aşamadığı vurgulanacaktır.

Esasen sorun sadece Türkiye'ye özgü değildir. 2000'li yılların demokratik tartışmaları, liderlerin güçlendiği ve halkın güçsüzleştiği bir liberal demokrasi krizine tekabül etmektedir (Tormey, 2015). Yaşanan krizden çıkış, demokrasinin daha geniş anlamda tanımlanması yönünde normatif bir çaba ile bu yönde çabaları güçlendirecek pratik eylemlerle mümkündür.Küresel çapta tartışılan demokrasilerin gerilemesi durumuna (Levitsky ve Way, 2010; Merkel 2004) Türkiye' nin artan biçimde örnek vaka olarak gösterilmesi, ülkenin yapısal sorunları kadar aktör 
Yıldırım, Y. (2022). Türkiye Demokrasisinde Çekişmeci Kolektif Eylemlerin Eksikliği.

Fiscaoeconomia, 6(1), 40-58. Doi: 10.25295/fsecon.1037892

düzeyinde de eksiklikleriyle ilgilidir. Harekete dayanan muhalif aktörlerin etkililiğindeki eksiklik, iktidar partilerinin ya da gücü elinde tutan elitlerin rolü kadar önemlidir.

Çalışmada öncelikle hareketlerle demokratik sistemler arasındaki bağlantılar genel hatlarıyla ortaya konduktan sonra, Türkiye özelinde dinamik çekişmeci aktörlerin eksikliği nedeniyle hareketlerin sistemi dönüştürmekte zorlandığı vurgulanmıştır. Tarihsel olarak 1990 sonrası süreçteki sivil toplum ve demokratikleşme yönündeki çabalara değinilse de özellikle yakın dönemdeki gelişmelere odaklanılmıştır.

\section{Hareketler ve Demokrasi}

Demokratikleşmenin ve toplumsal hareketlerin birbirini beslediği tezinden (Tilly, 2004) yola çıkarak, sivil dayanışma ağlarının veya ortak talep listelerinin geliştirdiği savların, hem ulusdevletin demokratikleşmesinde hem de demokrasinin yerleşik siyasal sistem olmasında başta Batı toplumları olmak üzere etkili olduğu görülebilir. Kamusal otoritelere yönelik tabandan yükselen düzenli baskılar, şikayetler, gerginlikler ve talepler monarşilerden cumhuriyete ve demokrasilere geçişte etkili unsurlardır. Bunları parlamenter düzende temsil etmek için, siyasal partilerin önemi 19. Yüzyıl sonlarında giderek artmıştır. Ancak kitlelerin talepleri çoğu zaman lider ve kurum eksenli hiyerarşik yapıların yukarıdan yönlendirdiği süreçte sönümlenmektedir. Bu durum barış̧ıl bir uzlaşıya ya da anlaşmaya varmak olarak görülebilir ki liberal demokrasiler böyle bir denge arayışı içindedir. Diğer taraftan, toplumsal hareketlerin sadece sivil toplum faaliyeti şeklinde görülüp belirli konuya ve işleyişe odaklanması, sistemin dinamik biçimde dönüştürülmesini engeller.

Genel bir çerçeve çizmek gerekirse, 1945 sonrası gelişen düzende farklı ekoller bu uzlaşının sürdürülmesine dayanır. Liberal demokrasiler için, rasyonel aktörler eliyle oluşturulan yasalar ve hukuk düzeniyle onların dayandığı kurumlar aracılığıyla işleyen düzenin devamlılığı esastır. Özellikle ABD-tarzı bireyci ve yarışmacı demokraside, hukuk-önünde eşitlik ve tercih özgürlüğü ile kurulmuş adaletin bozulmaması için yeni müdahaleler kolaylıkla sıra-dışı ya da irrasyonel ilan edilebilir. Bu yaklaşımın etkisiyle hareketleri davranış üzerinden incelemek, kontrol-dışı kalabalıklar imgesiyle birlikte kolektif taleplere mümkün olduğunca az alan bırakma eğilimindedir. Döngüsel seçim dönemleri, olası hareketlenmelerin siyasal karşılık bulacağı rutin etkinlikleri yansıtması için bu yüzden ısrarla öne çıkarılmıştır. Seçim yoluyla kitleleri temsil edecek kişilerin seçilmesi, doğrudan konuşmak yerine, temsilci aracılığıyla kalabalıkların susması anlamına gelir. Konuşma alanı için adres gösterilen sivil toplum ise bir yandan ekonominin bir yandan siyasal iktidar alanının dışındaki özel ve ahlaki taleplerle sınırlanmıştır. Hareketlerin rasyonel biçimde kuracağı kaynakların mobilizasyonu süreci, amaca ulaşmak için kar-zarar/fayda-maliyet analizleri içinde kalır (Crossley, 2002: 56, 77; Chester ve Welsh, 2011; della Porta ve Diani, 2020). Böylece demokrasinin teknik bir sürece indirgenmesi normalleşir; toplumsal hareketler de sistemin içinde sıradan birer unsur haline gelir.

Kitlelerin taleplerinin kontrolsüz ve yıkıcı sonuçlara ulaşacağı tespitiyle, demokratik elitizm (Schumpeter, [1950], 2021) Soğuk Savaş sürecinde demokrasinin halk demokrasilerine dönüşmemesinin bir yoluydu. Demokrasiye seçimler özelinde sınırlı katılım, kitlelerin irrasyonel taleplerini frenlemek için bir yol olarak görüldü. Ancak bireylerin katılımının yarattığı eksiklik, Batılı demokrasiler içinde her zaman tartışıldı. 1968 hareketlerinin etkisiyle birlikte, yüzyılın sonuna doğru müzakereci, katıımcı ya da güçlü demokrasi arayışları da, liberal 
Yıldırım, Y. (2022). Türkiye Demokrasisinde Çekişmeci Kolektif Eylemlerin Eksikliği.

Fiscaoeconomia, 6(1), 40-58. Doi: 10.25295/fsecon.1037892

demokrasilerin nasıl daha etkili işleyeceğine dair,aktif yurttaşlık ve çoğulculuk gibi kamusal boyutları öne çıkarmak isteğindeki normatif arayışlardı (Barber, 1995; Habermas, 1999; Demir, 2011; Mouffe, 2015). Bu çabalar, bilindiği üzere Soğuk Savaş sonrasında, kavramsal açıdan yönetişim kavramını güçlendirdi ve pratik düzeyde sivil toplumun karar alma süreçlerine daha etkili biçimde müdahalesinin önünü açtı. Ancak bir yandan da piyasadaki dengeleri koruma isteği içinde gelişen şirket-benzeri karar-alma süreçleri devletleri etkiledi. Buna bağlı olarak, işleyen pazar ekonomisi, siyaset ile piyasa arasındaki bağları geniş biçimde tanımlamaya başladı. Bu uzlaşma ve uyum arayışının küresel düzeyde geçerli bir mekanizma haline gelmesi, küresel sivil toplum kavramını güçlendirirken, aşırılıkları ve radikalizmi durdurmak ile karar süreçlerine katılım arasında bağlantı kuruldu. Öte yandan 2001 krizi ve özellikle 11 Eylül sonrası süreçte, hareketlerin yeniden karar-verme mekanizmalarında söz sahibi olmak isteği, liberal demokrasilerin bu teknik tıkanıklığına tepki olarak küresel hızlıca yükseldi.

Sosyalist sistemin halk demokrasilerinde ise söz konusu uzlaşının ideolojinin taşıyıcısı parti nezdinde olduğu kodlandı. Örgütlü mücadele bağlamında halkın ortaklaşmasını simgeleyen parti, Doğu Bloku pratiğinde gün geçtikçe liderlik ve üye-kadro ilişkisi içinde bir makineye dönüşürken bu kez liberal demokrasilerin seçim vurgusu gibi parti-içi disiplin ve doktrinler öne çıkarıldı. Devletin toplum karşısında güçlenmesi, sosyalizmi kurumların işleyişine ve kontrolüne bırakan başka bir tür teknik yarattı. Bu yüzden Soğuk Savaş'ın dengeleri içinde halkın talepleri çeşitli zamanlarda karşı-devrimci ya da fırsatçı olmakla suçlanmıştı.

Bu kutuplar arasında alternatif arayışları her zaman var olmuştur. Özellikle, en bilindik olanı, sosyal refah devleti ve sosyal demokrasi, 19. Yüzyılda monarşilerin dönüşümünde olduğu kadar II. Dünya Savaşı sonrası dönemin toparlanmasında da etkili rol üstlenmiştir. Sosyal demokrasinin parlamenter sistem aracılığıyla ve sosyal politikaları önemseyerek kurmaya çalıştığı denge,savaş sonrası doğan kuşakların yeni beklentileri ve 1970'lerin krizleri içinde gelişen neoliberalizm içinde gittikçe Amerikan tarzı bir kapitalizmin etkisiyle piyasaları önceleyen işleyişin içinde erimiştir.1968'in özgürlük arayışı, serbestleştirici etkisini 1989'a yansıtmıştır (Arrighi, Hopkins ve Wallerstein, 1995: 112). Bu açıdan liberalizmle demokrasi arasındaki en baştan beri kurulmaya çalışılan zor denge (Wallerstein, 2016: 100), Soğuk Savaş sonrasında kapitalizmin yuttuğu bir demokrasiye dönüşmüştür. Liberal siyasi özgürlüklerin piyasaların güvenliği karşısında gerilediği 11 Eylül sonrası dönemde işler iyice sarpa sarmaktadır. Güvenlikçi bakış açısından etkilenen demokrasi kavramı, çoğunlukla bir gerileme ya da otoriterleşme perspektifiyle tartışılmaktadır. Türkiye'nin örnek olay olmaya başladığı bu dalgada yaşananları yarışmacı otoriter (Levitsky ve Way, 2010; Esen ve Gümüşçü, 2016) veya otoriter neoliberal (Kaygusuz, 2018; Akçay, 2021) demokrasi olarak tanımlamak sıklaşmıştır. Bu çalışmalarda düzenli seçimlerin varlığı, hukuki işleyiş, serbest piyasa düzenine rağmen başta muhalif kesimlerin adil bir yarışma içinde olmadığı, piyasanın küresel bağlamdaki etkilerle birleşerek serbest değil kontrol altında bir dağılım yarattığı vurgulanmaktadır.

Türkiye demokrasisi, kuruluş dönemlerinden beri temel çıpa olan "muasır medeniyet seviyesi"ndeki gelişmelerden doğrudan etkilenmektedir. Batılı demokrasileri dönüşümü ile Türkiye siyaseti arasında doğrudan ve dolaylı ilişkiler bulunmaktadır. 1945 sonrası sürecin düzenli serbest seçimler eksenli liberal demokrasilerinden, 1960'ların kalkınmacı refah devletinde bürokrasi eksenli kamusal yatırımların öncülüğüne, 1968'in anti-emperyalist arayışlarından 1990'ların neoliberal eksenli yönetişim dinamizmine kadar süreçleri, az veya 
Yıldırım, Y. (2022). Türkiye Demokrasisinde Çekişmeci Kolektif Eylemlerin Eksikliği.

Fiscaoeconomia, 6(1), 40-58. Doi: 10.25295/fsecon.1037892

çok, farklı aktörler eliyle deneyimlemiştir (Keyder, 1989; Özbudun, 2000). Bu aktörler ve süreçler, Türkiye'yi Batı tarzı bir demokrasiye prosedürel olarak yaklaştırsa da tartışmaların demokrasinin alanını genişleten ve çoğulcu bir müdahaleyi mümkün kılan olasılıklıları sınırlı kalmıştır.

Türkiye'de demokrasinin seyri, Batı bloğunun gittikçe ABD tarzı bir siyaset ve ekonomi işleyişine dönüşmesiyle paralel olmuştur. Düzenli seçimler, çok partili hayat ve belirgin uluslararası örgütlere üyelikle liberal demokrasilerin yanında yer almaya çalışsa da kapitalizme eklemlenmede yaşanan sorunlara bağlı olarak, demokrasi de sorunlu biçimde gelişmiştir. Kurucu ilkelerde var olan çeşitli kamucu hedeflere rağmen, sosyalizmin temel güvenlik tehdidi olarak görülmesiyle planlı ekonominin etkisi sınırlı kalmış ve devamında bürokratik elitlere yönelik tepki, Doğu Bloku’ndaki gibi bir geçiş yaratmasa da sivil toplum üzerinden demokratikleşme düşüncesini güçlendirmiştir. Kısacası demokratik sistem kurma sorunu, Türkiye'ye özgü eksiklik olmamakla birlikte, siyasal sistemde halkın gücünü yansıtmak yönündeki girişimlerde taban inisiyatiflerinin belirleyici ya da etkili olma durumunun düşük olduğunu söylemek mümkündür. Hareketlerin sendika ve parti gibi hiyerarşik yapıları etkileme gücü, yukarıdan aşağı ve lider eksenli siyasetin güçlü olduğu pratikte, görece daha az olmuştur.

Ancak yukarıda belirtilen hatta iddia edildiği gibi, değişen siyasal sistem için otoriter(leşen) demokrasi tanımı, zaten tam anlamıyla demokratik olmayan bir işleyişin birden baştan aşağı bozulmadığı gerçeğiyle, yeterli bir tespit değildir. Çünkü bilindiği gibi demokratik işleyişte, başta ordu ve yargı olmak üzere, farklı kurumların etkisi her dönem çeşitli düzeylerde öne çıkmıştır. Ayrıca ülkedeki toplumsal muhalefetin, tarihsel süreçte zaman zaman geliştirmeyi başardığı karşı-savlar ve en nihayetinde seçim sonuçlarına yansıyan muhalif yüzdenin düzenli varlığı bir veri olarak önümüzdedir. Bu tartışmada üretilen kavramlar içinde sorunlu/kusurlu demokrasi (Merkel, 2004), Türkiye'yi nitelendirmek açısından daha doğru olabilir (Yıldırım, 2018). Türkiye'de muhalif taleplerin ve seçmen kitlesinin belli bir oranın altına inmemesi, temel bir gerçek halindedir. 2002'den bu yana yaşanan seçimlerde iktidarı değiştirme gücüne sahip olmasa da bu kitlenin iktidar tarafından -en güçlü dönemlerinde bile- dönüştürülemediği söylenebilir. Asıl sorun, muhalif kitlenin demokratikleşme yönünde uzun dönemli eylem eksikliği ve bu eylemlerin kurumsal siyasetin desteğiyle yükseltilememesidir. Kusurlu demokrasinin otoriterleşme eğilimi, kendisine karşı-çıkışlar güçlenebilirse durdurulabilir. Türkiye'deki siyasal sistemi analiz ederken karar-alıcı hegemon güçlerin etkisi kadar sistemin diğer unsuru olan bu kesimin varlığı ama sınırlı kalan etkisi de vurgulanmalıdır.

Bu çerçevenin ardından, çalışmanın altığını çizdiği nokta şudur ki siyaset, uzman, temsilci, 'bir bilen' önderliğinden çıkamadığı ölçüde, yöneten-yönetilen boşluğunun açıldığı, vekilin aslını belirlediği, halkın ikincil konumda kaldığı bir mekanizma kurulur. Halkın yönetimi demokrasi, ancak kolektif eylemlerin tabandan kurduğu dayanışma ağlarının toplumsal hareketlere dönüşmesi ölçüsünde siyasetin belirleyicisi olabilir. Yukarıda değinilen ve 20. yüzyılın ikinci yarısına dair bilinen gelişmelerdeki temel sorun budur. Ekonominin belirleyici olduğu ilişkiler çerçevesinde teknik bir iş haline gelen demokrasi, siyasal sistemin işlemesi için amaçtan ziyade araca dönüşür. Halkın onay verdiği temsilcilerin yönetimi, sınırlı bir demokrasidir. Kitlelerin seçim yoluyla belli bir oranda etkili olması, irrasyonel yorumların ve aşırı müdahalelerin durdurulması için bir yol olarak görülür. 
Yıldırım, Y. (2022). Türkiye Demokrasisinde Çekişmeci Kolektif Eylemlerin Eksikliği.

Fiscaoeconomia, 6(1), 40-58. Doi: 10.25295/fsecon.1037892

Kalabalıkların taleplerini duyurmak açısından yerleşik kurumsal siyasetin tıkanıklığı ve temsili demokrasinin krizleri yakın dönemin önemli tartışma konuları arasındandır (Tormey, 2015; Douzinas, 2015). Batı'da demokrasilerin düşüşü tartışması, aynı zamanda siyasal kavramların dönüşüm içinde olması bağlamında teorik tıkanıklıkla da yakından ilgilidir. Siyasal teorideki radikal ve dönüştürücü perspektiflerin önemli derecede zedelenmesine paralel olarak, toplumsal hareketlerin tabandan yükselen eylemlerinde, Öfkeliler ya da Sarı Yelekliler örneklerinde olduğu gibi, teorik çerçevesini netleştirmekten ziyade heterojen tepkilerin bir araya geldiği arayışları içermektedir. Bu hareketlerin yarattığı sınırlı etkinin henüz yapısal bir dönüşüme imkân tanımadığı açıktır.

Popülizm tartışmalarının da eklenmesiyle beraber, 2000'li yıllarda liberalizmin tanımladığının ötesinde yeni bir demokrasi bağlamı arandığı açıktır. Liberalizmin dışına çıkmayı bir tehdit olarak gören çalışmalar öne çıktığı gibi (Mudde ve Kaltwasser, 2019; Müller, 2020), bunun yeni bir söylemsel çerçeve kurmak için aracı olacağına, sosyal-demokrasiyi güçlendirebileceğine dair yorumlar da son dönemlerde artmaktadır (Mouffe, 2019). Bu sürecin birincisinden ikincisine doğru dönüşmesi, diğer deyişle temel insan hakları çerçevesinin dışına çıkmaması, yine hareketlerin geliştireceği kolektif mücadeleye bağlıdır. Bu mücadelenin sadece iktidar perspektifiyle sınırlı kalmaması, biyopolitik kapsayıcılıkta pratik hayatı yeniden demokratikleştirmeye çalışması sıklıkla vurgulanmaktadır (Hardt ve Negri, 2019).ABD tarzı yarışmacı demokrasinin kamusal talepleri yansıtmakta yeterli olmaması kadar, özellikle ekonomik krizlerle birlikte kapitalizmin yuttuğu demokrasinin sorunlarının iyice belirgin hale gelmesi, yakın zamanda toplumsal protestoların temel noktası olmuştur. Siyasal teorideki demokrasiye yönelik yeni arayışlar, bu pratik zeminden fazlasıyla etkilenmektedir.

Türkiye'deki siyasal sistem krizi ve demokrasi sorunu, siyasal teorideki arayışa etki eden tıkanıklıktan uzak değildir.Yeni siyasal açılımlara katkı sağlayacak hareketlerin eksikliği demokrasinin dönüşümünde hissedilmektedir. Türkiye, liberal bir demokrasinin seçim ve piyasa ilişkileri gibi özelliklerini taşısa da siyasal hakların genişlemesi yönündeki mücadelelerin eksikliğini her zaman hissetmektedir. Öte yandan Doğu Bloku ve Orta Doğu ülkelerinin, başta ordu ve bürokrasi olmak üzere,kitlesel müdahaleye kapalılık anlamında anti-demokratik kurumsal güçlerinin siyasal işleyişteki uzun süreli belirleyiciliği, kısmen azalsa da demokratik sistemin önemli eksiklikleri olarak göze çarpar. Toplumun yukarıdan aşağı disiplin içinde örgütlenebileceği düşüncesi ana eksen haline gelerek farklı aktörler tarafından sürdürülmeye çalışıımıştır (Özbudun, 2000; Uysal, 2017). Bu süreci farklı biçimde kuracak kolektif aktörler ise güçlenememiştir. Kurumsal sistemin gittikçe kişiselleşmesi, artan lider kültü, kolektif eylemlerin dönüştürücülüğünü engelleyen ana unsurlar arasında sayılabilir. Toplumsal mücadeleye yönelik, güvenlik eksenli siyasete bağlı biçimde gelişen, şeytanlaştırıcı söylem, teorik eksikliğin üstüne pratik bir engel olarak öne çıkar (Yıldırım, 2015).

1990'lardaki kusurlu demokrasinin getirdiği siyasal fırsat yapısı içinde güçlenen ve 1970'lerden bu yana dinamik bir hareket tabanına dayanan İslami geleneğin iktidar gücüyle devletleşmesi, devleti kontrol etmenin özgürleştirici ve demokratik siyasal sistemin tek yolu olduğu düşüncesinin tıkandığını gösterir. Kısacası iktidar gücü, özgürleştirici değil sabitleştirici bir nitelik taşır. Bu nedenle demokrasiyi hareketin içine yerleştirmek ve orada canlı tutmak gerekir. İktidarın ortak olanı kurucu niteliğini hareketin demokratikleştirici özelliğinden uzaklaştırdığımız ölçüde anti-demokratik bir siyasete doğru yol alırız. Aksi taktirde Türkiye'de 
Yıldırım, Y. (2022). Türkiye Demokrasisinde Çekişmeci Kolektif Eylemlerin Eksikliği.

Fiscaoeconomia, 6(1), 40-58. Doi: 10.25295/fsecon.1037892

de görüldüğü gibi, daha önce dışarıda bırakılanların hareketiyle kurulan yeni düzende bu kez içeridekiler, dışarıdakilerin payını almak için yeni müdahaleler yapmasına engel olur. Bilindiği gibi, demokrasi nefreti (Ranciere, 2014) bizim tanımladı̆̆ımız çizginin dışında kalanlar için yeniden geçerli hale gelir. Çünkü bu yaklaşımda, herkes kendi rolünü en iyi şekilde yapmalı ve verili rolün dışına çıkmamalıdır. Böylece oldukça dar tanımlanmış,bizim gibi olanların halk ve haklı sayıldığı, diğerlerinin ise dışarıda bırakıldığı demokrasi zemininde, dışarıdakilerin hepsinin güvenlik sorunu haline gelmesi mümkün olur. Bu döngüyü kırma potansiyeli, hareketlerin yeni sınırlar geliştirici siyasal zeminler kurma kapasitesindedir.

\section{Türkiye'de Çekişmeci Muhalefet}

Toplumsal muhalefetin gücü yerleşik sistemin sınırlarını zorladığı ölçüde bir siyasal sistem dinamizm içinde gelişir. Eylemlerin ürettiği savlara istinaden çeşitli sonuçlar yaratacak mekanizma ve süreçlerle yerleşik aktörlerle kuracağı etkileşim, sistemin niteliğini demokrasiye doğru dönüştürecek ekseni kurar (Tilly ve Tarrow, 2007). Kurumsal olan ve olmayan siyasetin bağlantısını kuracak bireysel veya topluluk düzeyinde ağların yaratacağı etkileşimler, sistemin demokratikleşmesinde veya demokrasinin yönünde etkili unsurlardır. Siyasetin dinamik gerginlikler üzerinden anlaşılmasını sağlayan bu yaklaşımda siyasal aktörler çeşitli değişim geçirirler. Değişimin çekişmelere dayanan bu sürecini anlamak esastır.

Türkiye'de ise bireysel taleplerin dönüştüğü kolektif eylemlerin çoğu zaman yerleşik siyasetin hiyerarşik kalıpları içine sıkışması, demokrasinin dinamik bir yapıda olmamasının göstergelerindendir. Muhalif hareketlerin kurumsal-olmayan, yakın dönemdeki tabirle yatay hiyerarşi içinde dönüştürücü ve değiştirici potansiyellerini hiyerarşik yapılara sıkıştırmak, ülkedeki demokrasinin önemli eksiklerinden biridir. Aşağıda değinilecek olan 1990 sonrası süreçte yer yer yükselen toplumsal taleplerin ifade bulduğu eylemler içinde gelişen yeni neslin kullandığı yeni araçların, önceki (yerleşik) aktörler tarafından tam olarak anlaşılamadığını ortaya koyar.

Esasen Türkiye'de erken dönemlerden bu yana muhalif örgütlenmeler her zaman itici ya da aşırılıkları frenleyici güce sahip olmuştur. Çalışmanın sınırlarını aşmakla birlikte, temel başlıklarını hatırlamak gerekirse, erken dönemlerden itibaren ilk Meclis'teki ikinci Grup'tan, çok partili hayata geçiş denemelerindeki girişimlere, Demokrat Parti bölünmesi ile değişen tek partili hayattan yine Demokrat Parti'nin bölünmesiyle ortaya çıkan Hürriyet Partisi gibi tepkilere kadar farklı sesler her zaman görülmüştür (Zürcher, 2013: 321-351). Kısacası yerleşik sistemi kontrol altında tutan güçlere karşı farklı örgütlenmeleri Türk siyasal hayatı her zaman deneyimlemiştir. 1960 sonrasında değişen uluslararası dengeler ve Soğuk Savaş koşulları içinde de sosyal ve siyasal haklar bağlamında örgütlenmeler hızlıca artmış ve çeşitlenmiş; milliyetçilikten İslamcılığa, devrimciliğin farklı yorumlarından mesleki birliklere kadar çeşitli dayanışma ağları kurulmuştur. Türkiye demokrasisi üzerindeki asıl mücadelenin bu süreçte başladığı söylenebilir.

Hareketlerin etkisi, sendikal mücadele ve devrimci eylemlerle iç içe geçmiş şekilde 1960 'lar ve 1970'ler boyunca gelişen tarihsel mirasa sahiptir (Kaynar, 2017; 2021). 1965'te TiP, 1977'de Ecevit önderliğindeki CHP ile kendini gösteren muhalif seslerin merkezi güçleri etkilemesi fikri, devletin aşkın yorumundan beslenen siyasal işleyişi aşmakta zorlanmıştır. Aslında hareketlerin silahlı mücadeleye dönüşmesi yolundaki temel etmenlerden biri de sistem-içi muhalefetin 
Yıldırım, Y. (2022). Türkiye Demokrasisinde Çekişmeci Kolektif Eylemlerin Eksikliği.

Fiscaoeconomia, 6(1), 40-58. Doi: 10.25295/fsecon.1037892

imkansızlaşmasıdır. Bu süreçte geliştirilen deneyimlerin ve örgütlenme çabasının önemsenmemesi mümkün değildir. Ancak silahlı mücadelenin ya da terörizmin yarattığı korku ve endişeyle kitleleri saflarına çekme beklentisi, Soğuk Savaş'ın bitimiyle beraber artık iyice imkânsız ve büyük oranda da etkisiz olmaya başlamıştır. Bu durum seçim ya da resmi siyaset dışındaki mücadelelerinin önemini azaltmaz; ancak kapsayıcılık ve yeni örgütlenme biçimleriyle dışarıdan içeriye, tabandan yukarıya baskı arayışı devam eder. Diğer bir deyişle hareketlerin kurulduğu "siyasal fırsat yapısı", 1990'ların sonuyla beraber değişmiştir. Bu açıdan Türkiye'deki toplumsal mücadelelerin temel hedefinin "daha iyi bir demokrasi" olması, Soğuk Savaş sonrasına denk gelir.

Tarihsel miras olan Batılılaşma ekseninde $A B$ ile ilişkiler bağlamında benzer sürecin gelişimi takip edilebilir. 1990'lar boyunca muhalif toplumsal hareketlerin beslendiği en önemli siyasal çerçeve, AB kriterleri olmuştur. Bu kriterler, 1982 Anayasası'nın güvenlikçi perspektifini önemli ölçüde esnetirken, "eski Türkiye"nin elitleri tarafından ülkenin parçalanması olarak görülmüştü. Geçen zaman içinde hareketlerin çekişmeci etkileşim ağlarını genişletemediği ölçüde, kadim devlet geleneğine yaslanan kurumsal yapı etkisini göstermiştir. 2000'lerde $A B$ 'nin kendi içinde yaşadığı krizlerle birlikte "yeni Türkiye"de de AB perspektifinden uzaklaşılmasının yine güvenlikçi söyleme bağlanması şaşırtıcı değildir.

1968 'in yeni toplumsal hareketlerinin mirası şeklinde farklı grupların parçalı hak taleplerinin 1990 'larda yükselmesi, sivil toplum faaliyetleri bağlamında Türkiye'de yansıma buldu. Bunun sistemi demokratikleştirilmesi bağlamında etkileri de görüldü. Örneğin, belli başlı örnekleri hatırlamak gerekirse, Sürekli Aydınlık İçin 1 Dakika Karanlık Kampanyası'ndan Bergama çevre mücadelesinin hukuk zeminini aşan pratik görünümüne kadar 1990'ların son dönemine damga vuran toplumsal hareketler gelişmişti. Belli konulara odaklanan eylemler dışında daha geniş başıklarda öğrenci ve kadın hareketleri, içlerindeki farklı eğilimleriyle birlikte, benzer şekilde bu dönemin hareket niteliğini güçlendiren önemli dayanışma ağlarını kurmayı başarmıştı. Insan hakları alanında ulusal ve uluslararası örgütlenmelerin etkileşimi de Anayasal değişikliklerin şekillenmesinde etkili oldu.

Ancak Türkiye'deki hareketler, bugünkü krizin temellerinin atıldığı 2000'li yılların başlarında gelişen küreselleşme karşıtı harekete eklenemedi; hatta büyük oranda bu konuyu gündemlerine dahi almadılar. 1990'ların küreselleşme dalgası, 2000'lerde küresel sivil toplum bağlamında hızlanırken Türkiye'deki hareketlerin bu süreçle kadın ve LGBT hareketi dışında örgütsel bağlamda etkileşim kurduğu söylenemez. 11 Eylül sonrası ABD eksenli uluslararası müdahalelere karşı çıkış bağlamında gelişen savaş-karşıtı mitingler, BarışaRock festivali gibi organizasyonlar, GDO'lu ürünlerin yaygınlaşmasına karşı gelişen çeşitli eylemler, uluslararası maden şirketlerine karşı yapılan çevre savunması dışında hareketlerin gündemi oldukça yerel kaldı. Bunun en büyük yansıması, 2010'da İstanbul'da gerçekleşen Avrupa Sosyal Forumu'nun oldukça sönük geçmesidir.

Toplumsal muhalefetin örgütlenmesinde siyasal parti düzeyinde de 2000 'lerin başından ilk dönmelerinde büyük bir belirsizlik yaşanmaktaydı. 1990'lar boyunca merkez sağ ve soldaki bölünmüş parti yapısı, koalisyon dönemleri olarak nitelendirilen hükümetleri zorunlu kılmıştır. Koalisyonun birlikte iş yapma, tavizler ve pazarlıklar gibi unsurları öne çıkaran zorunlu yapısı, demokratik genişlemeyi beraberinde getirmemiştir. Bugün parlamenter sistemin krizi olarak nitelendirilip yasama ve yürütme organlarının görevlerinde önemli değişikliklere yol açan ve 
Yıldırım, Y. (2022). Türkiye Demokrasisinde Çekişmeci Kolektif Eylemlerin Eksikliği.

Fiscaoeconomia, 6(1), 40-58. Doi: 10.25295/fsecon.1037892

cumhurbaşkanlığı hükümet sistemi adıyla resmileşen yeni süreç, bilindiği gibi bu yapısal krize dayanmaktadır. Bu süreç farklı boyutlarıyla -Türkiye akademisinin sınırlılıkları içinde, mümkün olduğu ölçüde- tartışıldı (Duru ve Üzgel [der.], 2013; Taşkın, 2013; Madra [yay. haz.], 2015; Bora [der.], 2016; Akça, Bekmen ve Özden [der.], 2018).

Türkiye'de demokratik devlet beklentisi, uzun süre, daha çok Kemalizm eleştirileriyle iç içe geçmiştir. Bu eleştirinin1990'lardan itibaren sivil toplumda etkinliğini artıran İslamcı söylem içerisinde güçlendiği söylenebilir. Güvenlik ve din eksenli olarak işleyen tartışmalar, daha köklü bir dönüşümün yaşanmasını engellemiştir. Sendikalar başta olmak üzere örgütlü muhalefetin rolü, çalışma hayatı ve ekonomiyi ikincil kılan güvenlik ve din tartışmalarının içinde kalırken, devletin korunması/ele geçirilmesi yönündeki sıkışma gündelik hayat içinden türeyen toplumsal konuların ve dönüşümün ana gündem olmasını da engellemiştir. Gündem yaratan toplumsal muhalefet örneklerinden, SEKA ve TEKEL özelleştirmelerine karşı yerel direnişler ve özellikle 2010 kışında Ankara'daki uzun süreli TEKEL eylemi gibi pratikler toplumsal muhalefetin kendi gündemlerini ortaklaştırarak kurabilmesi açısından hatırlatılması gereken örneklerdir (Yıkılmaz ve Kumlu [der.], 2011; Kolektif, 2011).

Yerel düzeydeki gündemlerin aktör ve dayanışma ağı krizlerinin yanı sıra uluslararası düzlemde de 1990'ların sonlarındaki değişim rüzgarlarından farklı bir hava vardı. 2002 Anayasa taslağı sonrasında Avrupa Birliği'nin ( $A B$ ) kendi içinde yaşadığı tıkanma, İngiltere ve Almanya başta olmak üzere sosyal-demokrat dönüşümü vaat eden partilerin gerilemesi, her iki ülkede muhafazakar merkez-sağın uzun süreli iktidarlarının temellerinin atılması, Fransa'da Sarkozy, İtalya'da Berlusconi iktidarlarının ülkedeki radikal-sağın gelişimine etki eden söylemleri,

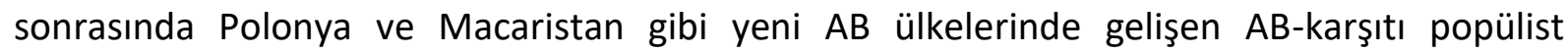
söylemler Avrupa açısından umut vaat etmeyen gelişmelerdi. 11 Eylül sonrasında yükselen güvenlikçi perspektifle beraber ABD'nin de artık liberal dünyada demokrasi ve özgürlük için meşru bir çıpa olmadığı açıktır. Uluslararası müdahalelerinin krizlere dönüşmesi kadar, ülke içinde siyahlara yönelik polis şiddetinin de durmadan devam etmesi, Trump'la beraber yükselen beyaz-üstünlüğü iddiaları ve göçmenlere yönelik ayrımcı uygulamalarla beraber, Batı dünyasında ilham verici farklı bir demokrasi önerisi ufukta görünmemekteydi.

Keza 2000'lerin başında küreselleşme-karşıtı hareketin merkezi haline gelen Latin Amerika'daki son yıllardaki gelişmeler iç açıcı değildi. Brezilya'daki 20 yıllık PT iktidarının yolsuzluk ve görevden alma gibi süreçlerin devamında Bolsonaro ile birlikte Trump benzeri bir iktidara dönüşmesi, Venezülla ve Bolivya'daki Chavez ve Morales sonrası krizler, alternatif bir sosyalist demokrasi fikrinin o bölgede de yerleşmediğini gösterdi. Böylece yerel hamlelerin uluslararası bir değişim dalgasına dönüşmediği ölçüde sınırlı etki yaracağı görülmüş oldu. Muhalif sesler, popülizmin küreselleşme-karşıtlı̆̆ını devralan etkisiyle birlikte demokratikleştirici değil tersine bir dalgayı tetikledi. Kısacası uluslararası siyasal fırsat yapısı da muhalif hareketlerin aleyhine gelişti. Bahsedilen gelişmeler ekseninde 2010 sonrası süreçte toplumsal muhalefetin dünya çapında kendine yol aradığı söylenebilir.

Türkiye de bu süreçten etkilenmektedir. Kapitalizmin normalleştiği bir demokrasi, artık daha çok sorgulanır hale gelmektedir. Küresel çapta neoliberalizmin piyasa öncelikli uygulamaları kitleleri, küreselleşmenin etkileşimlerine karşı daha tepkili hale getirdi. Ancak bunun kurumsal yansımaları bulunamamaktadır. Türkiye'deki siyasal hegemonyayı güçlendiren noktalardan biri de bu uluslararası krizdir. Uluslararası kurumlara, piyasalara, yerleşik partilere ve liderlere 
Yıldırım, Y. (2022). Türkiye Demokrasisinde Çekişmeci Kolektif Eylemlerin Eksikliği.

Fiscaoeconomia, 6(1), 40-58. Doi: 10.25295/fsecon.1037892

yönelik öfke, farklı ülkelerde alternatif ve kimi zaman da sürpriz isimleri hızlıca yükseltmektedir. Türkiye'nin görece istikrarlı ve uzun süreli siyasal iktidarı ile değişim arayışındaki kitlelere yönelik ilham kaynağı olmasının nedenlerinden biri budur. Özellikle Orta Doğu'daki insan hakkı ihlallerine ve işgallere yönelik yükseltilen söylemsel karşı çıkış ve değişim vurgusu, güçlü lider imajıyla birlikte bölgesel çapta ses getirdi.

Toparlamak gerekirse, toplumsal talepler 1990 'larla beraber küresel düzeyde sivil toplum ve yönetişim kavramları etrafında ilerlemiştir. 1970'lerden miras sosyalist devrim fikrinden uzaklaşıldıkça, sivil toplum faaliyetleriyle süreci demokratikleştirme beklentisi 1990'ların ikinci yarısında, $A B$ uyum paketleriyle beraber büyük oranda gerçekleşti. Bu arka-planın hızla değişen pek çok araçsal imkanlar ve nesillerin eline yeniden yorumlandığı görülebilir. Diğer deyişle mücadelenin nesnesi ve öznesi değişmektedir. Özellikle 1990 sonrası doğan kuşak için, üyelik tabanlı örgütlenme dışında, yatay hiyerarşiye dayanan çoklu aidiyetleri geliştirebilmek önemlidir. 1968' in gençlik hareketlerinden sonra, bir kez daha yeni aktörler var olan kurumsal yapıların, eskilerin işleyişini yeni araçlarla zorlamıştır. Bu kez yeni nesli harekete geçirmekte öne çıkan nokta olarak dünyayı değiştirmekten ziyade kendi dünyasını değiştirmek gösterilebilir. Gündelik hayata etki eden, aidiyet duygusunu kimlik, etnisite ya da kültürden önce hayatı yaşanılır kılan, gelecek umudu veren bir perspektifle sadece ideolojik değil duygusal bağları da içerecek şekilde bağlantıları arkadaşlık ya da dayanışma ağına çevirebilmek burada temel noktalar olacaktır.

Kısacası 12 Eylül sonrasında resmi ideolojinin ve bürokratik yapılanmanın karşısındaki muhalif hareketler içinde, İslami hareket ve partileri yukarıda bahsedilen ulusal ve uluslararası siyasi fırsat yapısını, kendi dinamiklerini geliştirerek ve etkili mekanizmalar kurarak lehlerine çevirmiştir. Gündelik hayata giren etkili bir örgütlenme hegemonyayı kuran süreci geliştirmiştir. Örneğin hükümet-dışı örgütlerin gücü arttıkça 2000'lerin başından itibaren hükümet-eksenli sivil toplum kuruluşları, yapının sağlamlaştırılması için önemli ölçüde katkı yaptı. Din, ekonomi ve eğitimin içe içe geçtiği yapılar birer güç odağı haline geldi.Böylece, demokrasiye sınırlı düzeyde ihtiyaç duyan neoliberal ekonomik sistem ile küresel gelişmelerin yerel yorumu biçiminde deforme edilmiş bir sivil toplum çalışması, Türkiye demokratik sisteminin son 20 yılda tartışılır hale gelmesinde iki ana hat olmuştur.

\section{4. Çekişme Ekseni Olarak Ekonomi}

Yukarıdaki kavramsal ve pratik gelişmeler içinde güçlenen ve başlardaki beklentinin tersine demokrasiyi olumsuz etkileyen muhafazakâr demokrasinin karşısında, muhalefet bloğunun yeterli dayanışma göstermediği açıktır. İlk dönemlerde şehirli kesimlerin laiklik ekseninde örgütlenmeye çalışıldığı 2007 Cumhuriyet Mitingleri bu alanda önemli bir mobilizasyon yaratmıştı. Tek eksende kalan bu taleplerin daha geniş bir dayanışma ağına evrilmemesi asıl önemli eksikliktir. İktidar gücü, farklı grupları bünyesinde topladıkça güçlenirken, çeşitli gerginlikleri de özellikle ekonomik gelişme bağlamında yönetmeyi başarmıştır. Yeni iktidar, değişimi vaat ederken ona direnen toplumsal muhalefet ise, bugün de aynı hatayı yaparak, eskinin daha iyi olduğu ve korunması gerektiği noktasını vurgulamıştır. Eskiyi canlandıracak liderlik arayışı ise olası değişimi yaratacak geniş cepheyi kurmak konusunda en büyük engel olmuştur. 
Yıldırım, Y. (2022). Türkiye Demokrasisinde Çekişmeci Kolektif Eylemlerin Eksikliği.

Fiscaoeconomia, 6(1), 40-58. Doi: 10.25295/fsecon.1037892

Yazının öne çıkardığı nokta, iktidar gücünün hegemonyasının temellerinin çekişmeci bir gerginliğe dayandı̆̆ıdır. Alevilerden Kürtlere, sosyalistlerden milliyetçilere farklı gruplarla ittifaklar, işbirlikleri ve dönem dönem öne çıkarılan "eski Türkiye"nin tıkanıklarıyla beraber krizdeki siyasetin açmazları iktidar bloğu tarafından yönetildi. Yakın zamanda kutuplaşma kavramıyla daha fazla anılan bu gerginlik, farklı durumlarda yeni pozisyonlar alma başarısını göstermekti. Ancak sorun, bugünkü siyasetin post-siyaset biçimiyle demokrasiyi bitirici noktaya evrilmesidir. Krizler karşısında üretilen çözümler, tabandan yürüyen kolektif eylemlerin sınırııı̆ında, sürecin demokratik bir bağlama oturmasını sağlamamaktadır. Tersine, kişisel etkiler, uzmanlık ve liderlik mefhumu daha keskinleşmektedir. Türkiye'nin bu genel küresel çizgiye savrulması şaşırtıcı olmasa da buna yönelik direniş olasılıklarını yükseltmemesi, sorunun büyümesindeki asıl nokta olarak öne çıkarılmalıdır. Demokratik siyaset için gerekli nokta, çekişmenin kontrolü için, gündelik hayata temas edecek farklı mekanizma ve süreçler yaratabilmektir.

Dolayısıyla demokratikleşme bağlamındaki temel konu, uzlaşma arayışındaki siyasetin uzlaşmazlıkları görmezden gelmeden ilerlemesidir. Eylemlerin sınır zorlayıcı pratikleri birbiriyle tek değil farklı bağlamlarda daha uzun etkileşimler, Laclau'nun (2007: 92-93) tabiriyle eşdeğerlik zincirleri, kurdukça etkili olacaklardır. Tabii ki bugün için pratikte asıl soru, kendi dışındakileri demokrasi-dışı ilan eden bir gücün karşısında neler yapılabileceğidir? Gittikçe otoriterleşen sistemin ve hukuki gelişmelerin aleyhine ilerlediği duruma bu süreç nasıl işleyecektir? Bu sorunun cevabı, yazı özelinde, hareketlerin somut ve kapsayıcı gündemle tabandan örgütlenebilmesinde saklıdır.

Tabii ki burada değişen iletişim araçları ve internetin etkisi yeni örgütlenme biçimleri için göz ardı edilemez. Bu katkının gelişimini sağlayan küreselleşmenin kültürel, sosyal, ekonomik etkisiyle birlikte mücadelenin etkileşim alanı sınırları aşmıştır. Böylece siyasal süreçleri daha geniş çerçevede, yeni etkileşimler ve koalisyonlar kurarak yaygınlaştırmak kolaylaşmıştır. Küreselleşme-karşıtlığı sürecinde bu deneyim gözle görülür hale gelişmiştir. Başta bölgesel etkileşimler olmak üzere, tartışılan kavram ve konuların küresel bağlamları göz ardı edilemez olmuştur. İnsan haklarının en geniş çerçevesi içinde artık demokrasinin kurulduğu zemin, küresel tartışmalar içinde şekillenir.

Gelinen noktada siyasetin çözüm üretmesi beklenen, aynı zamanda yerel ve küresel etkileşimin kurulabileceği ana ekseninin ekonomik bağlam olduğu söylenebilir.Yukarıda değinilen küreselleşmenin etkileri gittikçe tersine dönerken, demokrasinin krizi içinde ifade bulan popülist taleplerin yükselttiği karşı çıkışlar, özellikle ekonomi tartışmasını yeniden gündeme getirmektedir. Küreselleşmenin anti-demokratik işleyişi ve Kuzey-Güney hattında yarattığı küresel dengesizlik 2000'lerin başından itibaren sıkça vurgulanmıştır. Geçen sürede kapitalizmin sadece üretim ilişkileri üzerinden değil gündelik hayata girmiş, biyopolitik bir örgütlenme biçimi olarak siyasal bir güç haline geldiği görülebilir (Douzinas, 2015; Hardt ve Negri, 2019). Popülizmin yerel halkı öne çıkaran arayışları kadar heterojen halkın kendi içinde yeni ortaklaşma eksenleri aradığı da açıktır. Ekonomik bağlam burada bir araya getirici önemli bir hattı oluşturur (della Porta, 2015). 2008'ten itibaren Yunanistan'daki kemer-sıkma politikalarından, Öfkeliler'den İşgal Et Hareketi'ne, Geceleri Ayakta'dan Sarı Yelekliler'e kadar pek çok eylemde genç işsizliği, güvencesiz çalışma, küresel ekonomik kurumların yerel siyaset üzerindeki sorgulanamaz etkisi gibi başlıklar öne çıktı ve tartışmaların gündemini belirlemeye 
Yıldırım, Y. (2022). Türkiye Demokrasisinde Çekişmeci Kolektif Eylemlerin Eksikliği.

Fiscaoeconomia, 6(1), 40-58. Doi: 10.25295/fsecon.1037892

başladı. Arap Baharı'nın ikinci dalgası diyebileceğimiz Lübnan protestolarında da ekonomik krizin etkisinin bir türlü çözülemeyen siyasi tartışmalara yansıdığı görülebilir. Kısacası küresel çapta eylemlerin ana ekseninin ekonomik sorunlar ve buna çözüm üretemeyen temsili demokrasi ve onun dayandığı yerleşik eski siyasal kurumlara yönelik eleştiriler olduğu görülmektedir.

Türkiye' de ise kapitalizmin daha iyi bir demokrasi yönündeki engel olduğuna dair kapsayıcı bir karşı-hareket gelişmemiştir. Hareketlerle kapitalizm arasındaki eleştirel etkileşim, küreselleşme-karşıtı hareketin bütün dünyada yarattığı kırılmaya eklemlenemediği ölçüde yerel ve sınırlı kalmıştır. Hareketlerin 1990'larda kazandığı ivme, 2000'lerde küresel bağlama geçemediği ölçüde düşüşe geçmiştir. Bu noktada sosyal demokrasinin Avrupa çapında yaşadığı düşüşün Türkiye'deki yansımaları da etkili olmuştur. Kurumsal destekten yoksun hareketler kendi eksikleriyle birlikte gündem yaratma kapasitesini yitirmiştir.

Ülkenin her daim önemli sorunlarından olan ekonomik adaletsizlikler ve işsizlik gibi konuların hareketlerin daha çok gündemine gelmesi, bir yol olarak görülebilir. Bu bağlam, küresel tartışmalarla etkileşim açısından bağlantılar kuracaktır. Bilindiği üzere hızlı yapılaşma,betonlaşma, çarpık kentleşme ile beraber ekonominin dayandığı inşaat sektörünün sürdürülebilir bir ekonomi yaratmadığı, gittikçe hissedilen ekonomik kriz, yükselen enflasyon ve işsizlik oranlarıyla kendini göstermektedir. Yaşanan krize yönelik biçimde örgütlenecek bir sınıf ya da grup ise şu anda doğrudan işaret edilemez. Bu belirsizlik, günümüzün temel sorunudur. Ancak bir yandan da farklı kesimleri yakınlaştırmak gerektiği görülmektedir. Ortak hayatı doğrudan etkileyen ekonomik sorunlar, değişim arayan yeni hareket noktalarının örgütlenebileceği zemindir. Bu bağlamda özellikle yerel düzeyde, sektörel bazda dayanışma ve yardımlaşma ağlarının hareketlerin gelişeceği en geniş alan olacağı öngörülebilir.

2021 itibariyle ana muhalefet partisinin ve Millet İttifakı'nın bu yöndeki söylemleri ve gündemi yükseltmeye çalıştığı açıkça görülmektedir. Esasen burada toplumsal hareket dalgası yaratacak çerçevenin, CHP’nin daha önce geliştirdiği Adalet Yürüyüşü’ne dayandırılması mümkündür. Hukuk kurumlarına güven sorunu, alınan kararların meşruluğu tartışması, liyakat anlayışının çözülmesi gibi noktaların öne çıkarıldığı yürüyüş boyunca, uzun süre sonra ilk kez CHP gündemi belirleyen parti olmuştu. Antik Yunan'dan bu yana adalet,bir siyasal sistemin en temel ve eski tartışma noktalarından biri olarak normatif ve pratik boyutlarıyla oldukça kapsayıc boyutlar taşır. Demokrasi ile adalet arasındaki bağlantı, halkın gücünü etkili biçimde yansıtıp yansıtamayacağına dair önemli ekseni oluşturur. Bunun devamında ekonomik adalet tartışmasının da gündeme getirilmesi olasıdır. Daha önce Cumhuriyet Mitingleri ile daha dar bir zemine seslenme imkânı bulan muhalefetin, adalet ve özellikle ekonomik adalet gibi çerçevede geniş kesimleri bir araya getirme ihtimali yüksektir.

Benzer ortak cephe kuramama eğilimi daha sonra, 2010 Anayasa değişikliği referandumunda evet/hayır ikileminde, cumhurbaşkanı seçimlerinde siyaset-dışı aday bulma hevesinde görüldü. Seçim sisteminin değişmesiyle normalleşen ittifak sisteminde birbirine yakınlaşan aktörlerin, bu ortak eksen geliştirme pratiğini kısmen güçlendirdiği söylenebilir. Özellikle yerel seçimlerde İstanbul ve Ankara özelinde oluşan ortaklık, kapsayıcı bir söylemin pratik sonuçlar alabileceğini gösterdi.Bu tarz bir söylemin, ekonominin çeşitli alanlarında düzenli sorunlar yaşayan toplumun geniş kesimlerin hayatlarını daha iyi hale getirecek programlı birlikteliğe dönüşmesi gerekliliği açıktır. 
Yıldırım, Y. (2022). Türkiye Demokrasisinde Çekişmeci Kolektif Eylemlerin Eksikliği.

Fiscaoeconomia, 6(1), 40-58. Doi: 10.25295/fsecon.1037892

Kurumsal siyasetin ve büyük söylemlerin arasında kaybolan, iş güvencesi, güvencesiz çalışma, iş sağlığı gibi konuların sadece sendikaların eylem alanına bırakılması, siyasetin yeniden tanımlanmasındaki eksiklerden bir diğeridir. Uzun erimli sendikal direnişlerin muhalif partilerin desteğiyle gündeme taşınabilmesi, sendikaların emek hayatını güçlendirecek eylemleri sadece onların kurumsal kapasitesiyle sınırlı kalmaması önemlidir. Yakın zamanlarda yerel düzeydeki çevre protestolarından iş güvenliğine ve işten atılmalara yönelik iş yeri düzeyindeki sendikal mücadelelere kadar her bir noktada söz konusu eksilik yeniden yaşanmaktadır. Bu eylemlere dair zaman zaman parti temsilcilerinin bireysel destekleri ise kişisel inisiyatif düzeyinde kalmaktadır. Türkiye' de demokratik değişim yaratabilecek protesto ve eylemlerin birbiriyle etkileşim kuracak bağlantılar yaratabilmesi, kurumsal olan ve olmayan eylemlerin güçlü etkileşime girebilmesi, bu tip bağlantı noktalarının güçlendirilmesiyle ilişkilidir. Gezi Parkı dinamizminin sarstığı ama kendine getiremediği yerleşik yapı, liderin takip edildiği ve hiyerarşik eşitsizliği normalleştiren muhafazakârlığı beslemektedir. Bu sınırlı siyasal yorumdan çıkmak için, öncelikle gençlik ve kadın kolları gibi bilindik aracılar dışında çevre ve iklim gibi konulara odaklanan eylemleri, kurumsal-olmayan bağlamları, gündelik hayatı ve sıradan insan temasını önemsemek etkili yollardan biri olabilir.

2021 sonlarında yaşanan ekonomik kriz, ekonominin gündelik hayattan başlayan bir pratik olduğunun hatırlanması açısından bir kırılma yaratmıştır. "Geçinemiyoruz" başlığı ve sloganıyla hızla yayılan eylem ve protestolarda kurumsal bağları güçlendirmek için, lideri takip çizgisinin ötesinde, yeni bir siyasal dil ve etkileşim kurulması gerektiği açıktır. Yakın zamanlarda sokaklarda gezerek halka anlık ve yüz yüze temas kurma biçimi, kurumsallıkla bireysellik arasında salınan bir girişim olarak, yeni tarz siyasetin önemli araçlarından olmaktadır. Tabandan yükselen talepleri ifade etme ve gündelik hayat pratiklerini öne çıkarma açısından kayda değer bu girişimin seçim sürecinde diğer parti ve adayları da buna zorlayacağı açıktır.

\section{Sonuç}

Yazıda Tilly ve Tarrow'un çerçevesini çizdiği çekişmeci siyaset ve siyasal fırsat yapısı yaklaşımı üzerinden kurumsal-olmayan, taban hareketlerinin siyasal süreçleri yönlendirme etkisinin altı çizilmiştir. Çekişme, uzun erimli ısrarlı mücadele süreçlerini kapsar. Bu doğrultuda çekişmeci siyasetin kurumsal olan ve olmayan siyasi aktörler arasındaki sav-geliştirme faaliyetlerinin karşı çıkışları, kamu otoriterlerine yönelik sürdürdüğü ısrarlı tutumları, bu süreçte kurduğu pazarlık/aracılık, etkiyi yayma, yeni koalisyonlar kurma gibi mekanizmalar ve etkileşimler, Türkiye muhalefetinde belirleyici konumda değildir. Başta kadın hareketi olmak çeşitli uzun vadeli mücadelelerin kazanımları söz konusu olsa da kurumsal siyasetin hareketlerle bağlantısı düşük kalmıştır. Mevcut sistemde dönüşüm hedefleyen muhalif arayışların bu yönde bir bağ kurması gerekliliğinin altı çizilmiştir.

Toparlamak gerekirse, Türkiye'de siyasal sistemin niteliğine dair bir sorgulama, demokrasinin çekişmeci biçimde neden gelişemediğine dair arayışla iç içe geçer. Demokrasiyi daha demokratik hale getirecek hamleler, ya küresel düzeydeki gelişmelerde ya da bir liderin kitleyi peşinden sürüklemesinde aranmaktadır. Siyasal tartışmanın içindeki bu eksiklik, kökleri gündelik hayat içinde kurulan demokratik bir sistem olasılığını olumsuz etkilemiştir. Devletin kurumsal kapasitesini yönetme arayışı, siyasal iktidar hassasiyeti, toplumsal mücadelelerin önemini ikincil kılmıştır. 
Yıldırım, Y. (2022). Türkiye Demokrasisinde Çekişmeci Kolektif Eylemlerin Eksikliği.

Fiscaoeconomia, 6(1), 40-58. Doi: 10.25295/fsecon.1037892

Günümüzde mevcut hegemonyanın inşaat ve yapı sektörü, medya ve sivil toplum üzerinden kurduğu sosyo-ekonomik çıkar ağları kadar, demokratik güçlerin kur(a)madığı ağlar da siyasal sistem üzerinde etkili olmuştur. Durumu tersine çevirmek için, ortak hayatı şekillendiren konularda kurulacak dayanışma ağları oldukça önemlidir. Bu ağların geliştireceği dinamik etkileşim süreçlerinin dönüştürücü etkisi olacaktır. Güncel olarak, mevcut ekonomik kriz bu anlamda önemli bir fırsat çerçevesi sunar. Sosyo-ekonomik sorunları her dönem canlı olan bir toplumda demokratik sistemin kuruluşu, kamusal ortaklıkları artıracak pratiklerle mümkündür. Böylece farklı toplumsal kesimleri bir araya getirebilmek, örgütsüz kesimlerin katılımı ile üretilecek bir etkileşimle güçlenme potansiyeline sahiptir. Türkiye siyasi tarihinde bu yönde hareket-kurumsal siyaset ilişkisinin kurulamaması, önümüzdeki en büyük tıkanma noktalarındandır.

Sonuç olarak şu söylenebilir ki demokrasiyi siyasal sistemin merkezi yapacak unsur, seçim davranışları/sonuçları ve hukuki boyutun yanında tabandan itibaren gelişen katılım pratikleri, kolektif eylemler ve toplumsal hareketlerin süreci yönlendirme etkisidir. Hareketlerin siyasal fırsatları demokratikleştirecek kolektif eylemleriyle dönüştürülecek bir siyasal işleyiş, sistemi farklı kılacaktır. Hareketlere yönelik suçlayıcı dil, şeytanlaştırma faaliyetleri, terör ve ihanet benzeri ilişkilendirmeler de yine bu eylemlerin ısrarcı ve dayanışmacı nitelikleriyle aşılabilir. Tabandan yükselen süreçler kadar kurumsal siyasetin tabanla ilişkilerini güçlendirecek perspektif değişikliği de söz konusu dönüşümün güçlendirilmesi için elzemdir. Ayrıca bu köklü bakış açısı değişikliği, devlet eksenli analizler ve kurumsal iktidarın baskın ve baskıcı niteliklerini değiştirmek anlamına gelecektir.

\section{Kaynakça}

Akça, İ., Bekmen, A. ve Özden B. A. (der.) (2018). "Yeni Türkiye”ye Varan Yol, İletişim, İstanbul.

Akçay, Ü. (2021). "Authoritarian consolidation dynamics in Turkey", Contemporary Politics, 27(1): 79-104.

Arat, Y., and Ş. Pamuk (2019). Turkey Between Democracy and Authoritarianism. Cambridge: Cambridge University.

Arrighi, G., Hopkins, T. ve Wallerstein, I. (1995). Sistem Karşıtı Hareketler, Çev. C. Kanat, B. Somey, S. Sökmen, Metis, İstanbul.

Babacan, E., M. Kutun, E. Pınar and Z. Yılmaz, eds., (2021). Regime Change in Turkey: Neoliberal Authoritarianism, Islamism and Hegemony. London: Routledge.

Barber, B. (1995). Güçlü Demokrasi, Çev. Mehmet Beşikçi, Ayrıntı, İstanbul.

Bora, T. (der.) (2016). Inşaat Ya Resulullah, iletişim, İstanbul.

Chester, G ve Welsh, I. (2011). Social Movements - The Key Concepts, Routledge, Londra.

Crossley, N. (2002). Makinse Sense of Movements, Open University, Buckingham.

Della Porta, D. (2015). Social Movements in Times of Austerity: Bringing Capitalism Back into Protest Analysis, John Wiley \& Sons, Londra.

Della Porta, D. ve Diani, M. (2020). Toplumsal Hareketler, Çev.Pelin Çakır, Ceren Gülbudak, İ̧̧ Bankası, İstanbul. 
Yıldırım, Y. (2022). Türkiye Demokrasisinde Çekişmeci Kolektif Eylemlerin Eksikliği.

Fiscaoeconomia, 6(1), 40-58. Doi: 10.25295/fsecon.1037892

Demir, G. (2011). "Habermas ve Foucault: Müzakereci demokrasi ve yönetimsellik” Akdeniz iiBF Dergisi 11(22): 48-71.

Doğan, S. (2016). Mahalledeki AKP, İletişim, İstanbul.

Douzinas C. (2015). Krizde Felsefe ve Direniş, Çev. Tulga Buğra Işık, Metis, İstanbul.

Duru, B. ve Üzgel, í. (der.) (2013). AKP Kitabı, Phoneix, Ankara.

Esen, B., ve Gümüşçü, S. (2016). "Rising competitive authoritarianism in Turkey", Third World Quarterly, 37(9): 1581-1606.

Fominaya, C. F. (2020). Social Movements in a Globalized World. London: Red Globe.

Habermas, J. (1999). "Demokrasinin üç normatif modeli", Benhabib, S. (der.), Demokrasi ve Farklıık: Siyasal Düzenin Sınırlarının Tartışmaya Açılması içinde, Çev. Z. Gürata ve C. Gürsel, Demokrasi Kitaplığı, İstanbul, 37-50.

Hardt, M. ve Negri, A. (2019). Meclis, Çev. Akın Emre Pilgir, Ayrıntı, İstanbul.

Kaygusuz, Ö. (2018). "Authoritarian neoliberalism and regime security in Turkey: Moving to an 'exceptional state' under AKP", South European Society and Politics, 23(2): 281-302.

Kaynar, M. K. (der.) (2017). Türkiye'nin 1960'ı Yılları, İletişim, İstanbul.

Kaynar, M. K. (der.) (2021). Türkiye'nin 1970'li Yılları, Illetişim, İstanbul.

Keyder, Ç. (1989). Türkiye'de devlet ve sınıflar. İletişim, İstanbul.

Kolektif (2011). Tekel Direnişi Işığında Gelenekselden Yeniye Iş̧̧i Sınıfı Hareketi: Nota Bene, Ankara.

Laclau, E. (2007). Popülist Akıl Üzerine, Çev. Nur Betül Çelik, Epos, Ankara.

Levitsky, S. ve Way, L. A. (2010). Competitive Authoritarianism: Hybrid Regimes After The Cold War, Cambridge University, Cambridge.

Madra, Y. M. (yay. haz.) (2015). Türkiye'de Yeni Iktidar ve Yeni Direniş, Metis, İstanbul.

McAdam D., Tarrow S. ve Tilly, C. (2001). Dynamics of Contention, Cambridge University Press, Cambridge.

Merkel, W. (2004). "Embedded and defective democracies", Democratization, 11(5), 33-58.

Mouffe, C. (2015). Demokratik Paradoks, Çev. Ahmet Cevdet Aşkın, Epos, İstanbul.

Mouffe, C. (2019). Sol Popülizm, Çev. Aybars Yanık, İletişim, İstanbul.

Mudde, C. ve Kaltwasser, C. R. (2019). Popülizm Kısa Bir Giriş, Çev. Erdem Türközü, Nika İstanbul.

Müller, J. W. (2020). Popülizm Nedir?, Çev. Onur Yıldız, İletişim, İstanbul.

Özbudun, E. (2000). Contemporary Turkish politics: Challenges to democratic consolidation. Lynne Rienner Publishers.

Ranciere, J. (2007). Siyasalın Kıyısında, Çev. Aziz Ufuk Kılıç, Metis, İstanbul.

Ranciere, J. (2014). Demokrasi Nefreti, Çev. Utku Özmakas, Illetişim, İstanbul. 
Yıldırım, Y. (2022). Türkiye Demokrasisinde Çekişmeci Kolektif Eylemlerin Eksikliği.

Fiscaoeconomia, 6(1), 40-58. Doi: 10.25295/fsecon.1037892

Schumpeter, J. (2021). Kapitalizm Sosyalizm ve Demokrasi, Çev. Vedat Ahsen Coşar, Dorlion, İstanbul.

Tansel, C.B. (2018). "Authoritarian neoliberalism and democratic backsliding in turkey: beyond the narratives of progress", South European Society and Politics 23 (2): 197-217.

Tarrow S. (2021). Movements and Parties, Cambridge University, Cambridge.

Taşkın, Y. (2013). AKP Devri, İletişim, İstanbul.

Tilly, C. (2004). Toplumsal Hareketler 1768-2004, çev. Orhan Düz, Babil, i̇stanbul.

Tilly, C. ve Tarrow, S. (2007). Contentious Politics, Paradigm, Boulder.

Tormey, S. (2015). The End of Representative Politics, Polity, Londra.

Uysal, A. (2017). Sokakta Siyaset, İletişim, İstanbul.

Wallerstein, I. (2016). "Liberalizm ve Demokrasi”, Bildiğimiz Dünyanın Sonu içinde, Çev. Tuncay Birkan, Metis, İstanbul.

Yıkılmaz, G. ve Kumlu, S. (der.) (2011). Tekel Eylemine Kenar Notları, Phoneix, Ankara.

Yıldırım, Y. (2015). “Anarşistten teröriste marjinalden çapulcuya: Toplumsal hareketlerin şeytanlaştırılması", Öteki'nin Var Olma Sancısı içinde, ed. İsmet Parlak, 483-508, Bursa, Dora.

Yıldırım, Y. (2018). “Demokrasilerde otoriterleşme ve hibrid rejim tartışmaları ve Türkiye'ye dair çıkarımlar", Politik Ekonomik Kuram, 2(2): 1-26.

Yörük, E. ve Yüksel, M. (2015). “Gezi eylemlerinin toplumsal dinamikleri”, Toplum ve Bilim, 133: $132-165$.

Zürcher, E. J. (2013). Modernleşen Türkiye'nin Tarihi. 28. Baskı, İletişim, İstanbul.

Etik Beyanı: Bu çalışmanın tüm hazırlanma süreçlerinde etik kurallara uyulduğunu yazar beyan eder. Aksi bir durumun tespiti halinde Fiscaoeconomia Dergisinin hiçbir sorumluluğu olmayıp, tüm sorumluluk çalışmanın yazarına aittir.

Ethics Statement: The author declares that ethical rules are followed in all preparation processes of this study. In case of detection of a contrary situation, Fiscaoeconomia has no responsibility and all responsibility belongs to the author of the study. 
Yıldırım, Y. (2022). Türkiye Demokrasisinde Çekişmeci Kolektif Eylemlerin Eksikliği.

Fiscaoeconomia, 6(1), 40-58. Doi: 10.25295/fsecon.1037892

The Lack of Contentious Collective Actions in Turkish Democracy

Yavuz YILDIRIM

\section{Extended Abstract}

Collective actions from below and their political demands have had a historical role in the institutional formation of politics. One of the most important elements that make a political system democratic is the existence of opposition groups and their ability to be heard. The contention and conflict of different views, the competition (for liberal democracies) and eventually the ability to develop various alliances and comproAmises form the foundations of modern democratic functioning. In order for this environment to be maintained in a peaceful way, the political functioning of collective actions and the social movements that they transform into in the long term must have democratizing qualities in terms of the representation of different groups. Although there have been many development and breakthrough processes in the history of democracy in Turkey, it can be said that one of the most important shortcomings in the process is that institutional politics cannot be guided by the collective actions of social movements. On the other hand, political parties do not want to be associated with such collective protests. This distance between institutional politics and grassroots democracy is one of the structural crises of the country's failure to democratize.

Aside from the decision makers and power centers, the analysis of a political system also includes the opposition forces."Does Turkey have strong social opposition and effective social movements nurtured within it?" will analyze the link between the lack of decisive power of social movements and Turkish democracy. Recent studies in this area seem to focus on the authoritarian tendencies of the long-term ruling power and changing economic policies (Tansel, 2018; Arat and Pamuk, 2019; Çınar, 2019; Babacan et al. (eds.), 2021). The importance of movements in determining the actors and issues in political processes continues to be widely discussed (Fominaya, 2020). However, this line cannot be said to be strong in Turkish literature. The study aims to make a contribution to this deficiency. Although the views on Turkish politics through protests increased (Uysal, 2017) and -although at a very low level when compared to foreign academic sources-- political system and democracy analyzes increased in Turkish, especially with the Gezi Park protests, through social movements (Öğütle and Göker (ed.), 2014); Yörük and Yüksel, 2015).

However, here, it is based on an axis that is not very common in Turkey in the literature of movements. The study, which will continue with reference to the concepts of dynamics of contention and contentious politics (McAdam Tarrow \& Tilly, 2001; Tilly \& Tarrow, 2007) and the political opportunity structure approach, will focus on the deficiencies in democratic argumentation and development in the political system in Turkey. The claim of the study, which tries to reveal a different basis of current debates by leaning on the conceptual and historical background, is that the lack of democracy based on grassroots actions prevents the democratization norms tried to be developed in Turkey from being based on solid foundations. Because of the networks that democratic actors have difficulty developing, the political system, institutional politics and ultimately the state are defined by personal interventions. As well as the socio-economic interest networks established by the current hegemony over the construction and building sector, the media and civil society, networks 
Yıldırım, Y. (2022). Türkiye Demokrasisinde Çekişmeci Kolektif Eylemlerin Eksikliği.

Fiscaoeconomia, 6(1), 40-58. Doi: 10.25295/fsecon.1037892

that democratic forces have not (could) establish have had an impact on the political system. This finding does not mean that the tradition of social struggles, trade union struggles or party initiatives in the past are ignored. However, the ineffectiveness of movements in influencing public policy is a clear case. Here, the position of the movements in the democratic system is discussed, not a point that contradicts their dynamism, such as the success or failure of the movements. It will be argued that this deficiency prevents the political process from transforming into a different form from the bottom up.

The proposition of the study is that the democratic capacities of the structures decrease as their connection with the movements decreases. This determination will also contribute to Ranciere's $(2007$; 2014) hatred of democracy, created by those who control the order by the disruptive interventions of the politics of conflict and the critical search of recent political theory between movements and institutional politics (Douzinas, 2015; della Porta, 2015; Mouffe, 2019; Hardt and Negri, 2019; Tarrow, 2021). In these studies, which highlight points such as coordination, strategy, leadership, and setting common goals in increasing the impact of movements in practical politics, not only the recognition and rights demands of certain groups, but also how to develop efforts to shape common life on a global scale are discussed. In this framework, it will be emphasized in the article that democracy, which is not supported by the coercive actions and interventions of the movements, cannot overcome the vicious circle of technicalized decision-making mechanisms.

In fact, the problem is not unique to Turkey. The democratic debates of the 2000s correspond to a crisis of liberal democracy, in which leaders are empowered and the people are weakened (Tormey, 2015). The exit from the current crisis is possible with a normative effort to define democracy in a broader sense and practical actions that will strengthen efforts in this direction. The increasing use of Turkey as a case study for the decline of democracies discussed globally (Levitsky and Way, 2010; Merkel 2004) is related to the country's structural problems as well as its shortcomings at the actor level. The lack of effectiveness of opposition actors based on the movement is as important as the role of ruling parties or power-holding elites.

In the study, after the connections between the movements and democratic systems were outlined, it was emphasized that the movements had difficulties in transforming the system due to the lack of dynamic competing actors in Turkey. Although the efforts for civil society and democratization in the post-1990 period have been mentioned historically, recent developments have been especially focused on. 